ACTA MYCOLOGICA

Vol. 44 (2): 233-238

2009
Dedicated to Professor Krystyna Czyżewska

in honour of 40 years of her scientific activity

\title{
Cladonia metacorallifera, a lichen species new to the Eastern Carpathians
}

\author{
PIOTR OSYCZKA ${ }^{1}$ and ROBERT KOŚCIELNIAK ${ }^{2}$
}

\author{
${ }^{1}$ Department of Polar Research and Documentation, Institute of Botany \\ Jagiellonian University, Kopernika 27, PL-31-501 Kraków, piotr.osyczka@uj.edu.pl \\ ${ }^{2}$ Department of Botany, Institute of Biology, Pedagogical University of Kraków, Podbrzezie 3 \\ PL-31-054 Kraków
}

Osyczka P., Kościelniak R.: Cladonia metacorallifera, a lichen species new to the Eastern Carpathians. Acta Mycol. 44 (2): 233-238, 2009.

A rare lichen Cladonia metacorallifera was found in the Bieszczady Mts. and this is the first report of the species from the Eastern Carpathians. In Poland, its occurrence is probably limited to small populations scattered in high mountain situations. The data of distribution of the species in Poland, ecological characterization of the new locality and some taxonomical remarks concerning the recorded specimen, as well as a photograph of its habit are provided.

Key words: lichens, section Cocciferae, distribution, ecology, Bieszczady Mts.

\section{INTRODUCTION}

Cladonia metacorallifera Asahina is a fruticose, cup-shaped and red-fruited member of the section Cocciferae (Delise) A. Evans (Fig. 1). The huge variability of the morphology of the species in this group causes many problems in their taxonomy and identification (e.g., Stenroos 1989a; Osyczka 2009). Generally, the podetia of $C$. metacorallifera are throughout densely covered by squamules, microsquamules and/ or cortical granules, and furthermore decorticated parts are often blackened, especially towards the tips of podetia. The thallus contains usnic, didymic and squamatic (or thamnolic) acids and this chemical feature is diagnostically important because it differentiates the species from morphologically similar cup-shaped Cladonia from the section (e.g., C. coccifera (L.) Willd., C. diversa Asperges and C. borealis S. Stenroos). The significant morphological and chemical differences between C. metacorallifera and other scyphose lichens with red apothecia are discussed in several papers (e.g., Stenroos 1989b; see also Kowalewska, Kukwa 2004; Osyczka et al. 2006). 


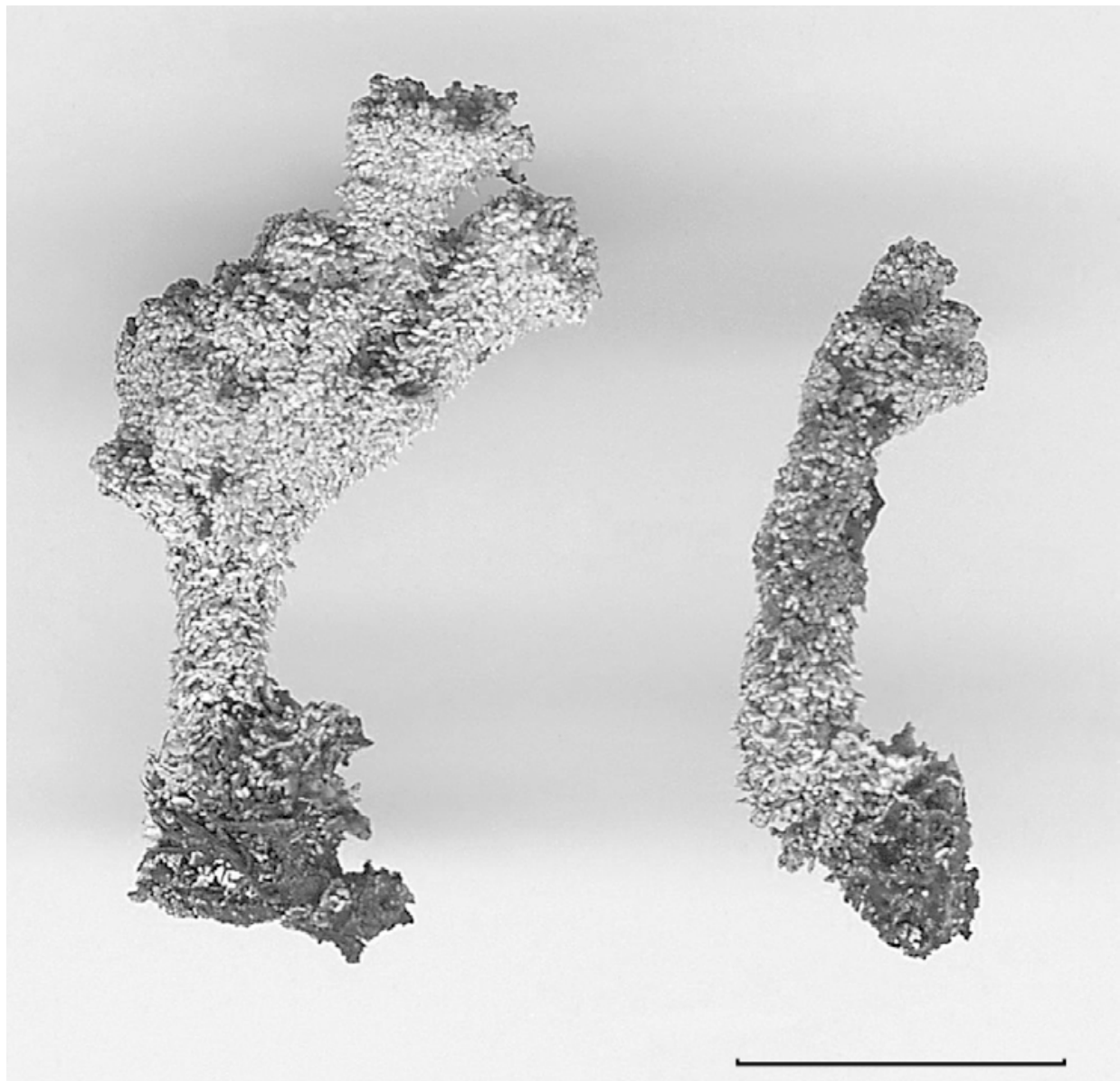

Fig. 1. Specimen of Cladonia metacorallifera from the Bieszczady Mts.

(leg. J. Kiszka, R. Koscielniak, 13 July 2005, KRAP-L). Scale bar $=1 \mathrm{~cm}$.

The Bieszczady Mts. are an important centre of lichen biodiversity in Poland (e.g., Czyżewska 2003; Kościelniak 2007, 2008). The intensive lichenological field research in this region carried out in the last decade still provides new information about the occurrence and distribution of lichens in Poland and the Carpathians. During a critical revision of lichen materials belonging to Cladonia coccifera s.l. deposited in Herbarium KRAP-L, one specimen from the Bieszczady National Park turned out to be Cladonia metacorallifera. This is the first report on the taxon in this mountain range, as well as in the whole area of the Eastern Carpathians. 


\section{MATERIAL AND METHODS}

The revision of Cladonia coccifera s.l. specimens housed in KRAP-L (Pedagogical University of Kraków) was done using standard microscopic techniques supported by chemical analysis. Lichen substances were determined by TLC in solvent A and C (acc. to Orange et al. 2001). Metter-Toledo SevenEasy $\mathrm{pH}$ meter was employed for substratum $\mathrm{pH}$ determination. The analysis was made by suspending substrate matter in pure water. All known Polish localities of Cladonia metacorallifera are mapped according to the ATPOL grid square system (Zając 1978; modified by Cieśliński, Fałtynowicz 1993). The grid square $1 \times 1 \mathrm{~km}$ was used for showing the precise locality in the Bieszczady National Park.

\section{RESULTS AND DISCUSSION}

Cladonia metacorallifera Asahina, J. Jap. Bot. 15: 612 (1939).

It is a new component of the epigeic biota of mountain pasture lichens in the Bieszczady Mts. (Fig. 2). It was recorded only on W slope of Rozsypaniec massif,

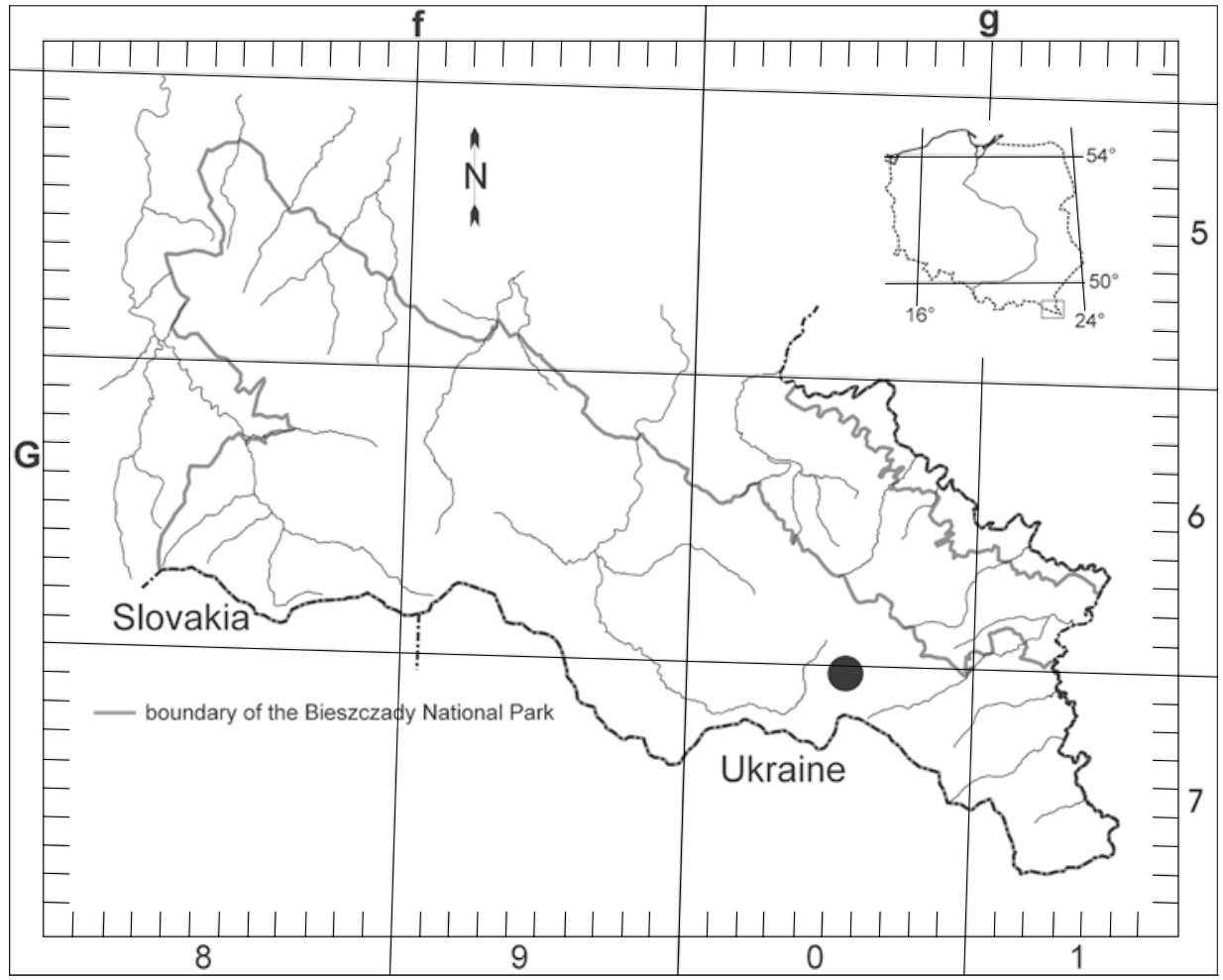

Fig. 2. Locality of Cladonia metacorallifera in the Bieszczady Mts. 


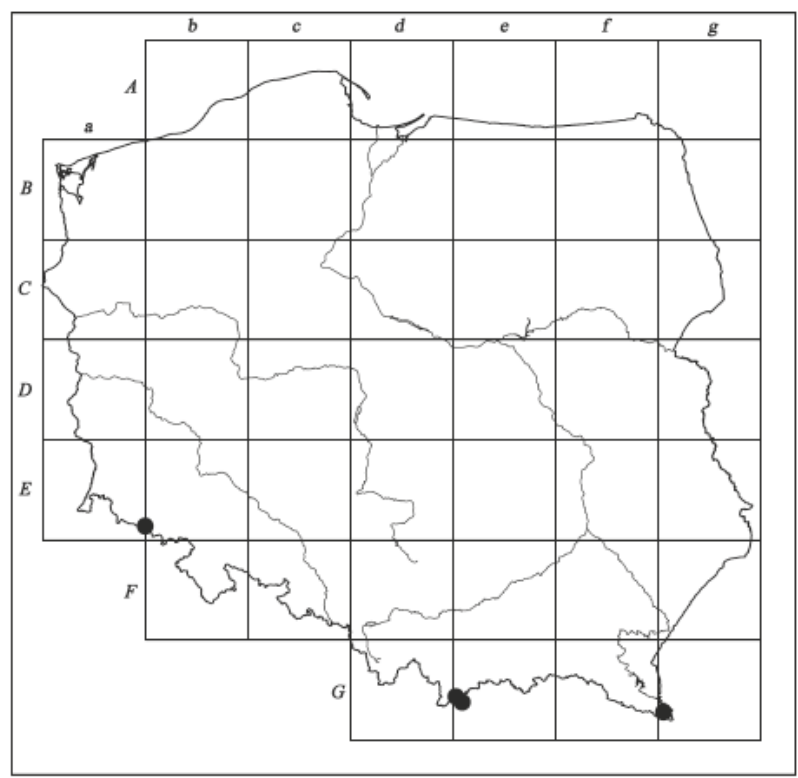

Fig. 3. General distribution of Cladonia metacorallifera in Poland.

rocky rubble above upper forest border, exposition SW, alt. $1153 \mathrm{~m}, 49^{\circ} 03^{\prime} 46.4^{\prime \prime} \mathrm{N}$, $22^{\circ} 45^{\prime} 52.0^{\prime \prime} \mathrm{E}$ [Gg 7005].

The specimen grew on humus between mosses in an open and sunny area. The $\mathrm{pH}$ level 4.65 of substrate matter was determined and such substrate can be qualified as strongly acidic. C. metacorallifera was associated with other Cladonia species (e.g., C. fimbriata (L.) Fr., C. gracilis (L.) Willd., C. rangiferina (L.) Weber ex F. H. Wigg., C. squamosa Hoffm., C. coniocraea (Flörke) Spreng., C. coccifera (L.) Willd., C. glauca Flörke, C. pleurota (Flörke) Schaer.) and also Cetraria islandica (L.) Ach., Lempholemma chalazanum (Ach.) de Lesd., Placynthiella oligotropha (J. R. Laundon) Coppins \& P. James and Trapeliopsis granulosa (Hoffm.) Lumbsch.

The specimen from the Bieszczady Mts. is modified by severe climate factors occurring on the locality (for example: long period of snow cover, strong wind, low temperature). It is squat and augmentative with swollen scyphi at the end of the podetia. Podetial surface is densely covered by squamules and microsquamules (Fig. 1). Such morphological modifications are frequently observed among Cladonia specimens growing in high mountains and polar regions (cf. Osyczka 2004; Osyczka 2006; Osyczka et al. 2007).

Cladonia metacorallifera was described by Asahina (1939) from Japan and at present it is also known from several countries in Europe, North and South America (see Osyczka et al. 2006 and literature cited therein). Generally, the species appears in the boreal and temperate zones, especially in high mountain and alpine belts (e.g. Wirth 1995). In the Carpathians the species has been found in the Tatra Mts. in Poland and Slovakia (Pišút 1997; Kowalewska, Kukwa 2004; Osyczka et al. 2006). It has not been noted in the Eastern Carpathians so far, and here the locality in the Polish part of the Bieszczady Mts. is added (Figs 2, 3). Polish records of C. metacorallifera 
also include one situation in the Karkonosze Mts. (Kowalewska, Kukwa 2004 - Fig. 3). A taxonomical revision of Cladonia coccifera s.l. deposited in Polish herbaria did not provide any further $C$. metacorallifera localities. It seems that in Poland the lichen is a rare species and its occurrence is limited to small populations scattered in the highest mountainous areas along the southern country border.

Acknowledgements. A part of this research was supported by the Ministry of Science and Higher Education (grant No N N305 2012 35). We would like to thank an anonymous reviewer for helpful remarks and corrections of the manuscript.

\section{REFERENCES}

Asahina Y. 1939. Japanische Arten der Cocciferae (Cladonia-Coenomyce). J. Jap. Bot. 15: 602-620.

Cieśliński S., Fałtynowicz W. (eds). 1993. Atlas of the geographical distribution of lichens in Poland. 1. W. Szafer Institute of Botany, Polish Academy of Sciences, Kraków.

Czyżewska K. 2003. Evaluations of the threat to lichens in Poland. Monogr. Bot. 91: 241-249.

Kowalewska A., Kukwa M. 2004. Cladonia metacorallifera (lichenized Ascomycota, Cladoniaceae) new to Poland and additional record from Slovakia. Biologia, Bratislava 59 (4): 433-434.

Kościelniak R. 2007. Usnea florida - threatened species of rich biotopes in the Polish Eastern Carpathians. Acta Mycol. 42 (2): 281-286.

Kościelniak R. 2008. The importance of primeval and natural forests to preservation of species diversity of lichens in the Bieszczady Mts. Roczniki Bieszczadzkie 16: 67-76.

Orange A., James P.W., White F. J. 2001. Microchemical methods for identification of lichens. British Lichen Society, London, 101 pp.

Osyczka P. 2004. Cladonia macroceras (Delise) Hav. (In:) U. Bielczyk, S. Cieśliński, W. Fałtynowicz (eds). Atlas of geographical distribution of lichens in Poland. 4. W. Szafer Institute of Botany, Polish Academy of Sciences, Kraków: 29-33.

Osyczka P. 2006. The lichen genus Cladonia (Cladoniaceae, lichenized Ascomycota) from Spitsbergen. Pol. Polar Res. 27 (3): 207-242.

Osyczka P. 2009. Cladonia diversa (Cladoniaceae, lichenized Ascomycota) - overlooked lichen in Poland. Acta. Soc. Bot. Pol. (in print).

Osyczka P., Węgrzyn M., Flakus A. 2006. Two species of the genus Cladonia (Cladoniaceae, lichenized, Ascomycota) new to the Polish Tatra Mts. Polish Bot. J. 51 (2): 233-235.

Osyczka P., Flakus A., Węgrzyn M., Cykowska B. 2007. Cladonia crispata var. cetrariiformis (Cladoniaceae, lichenized Ascomycota) in the Tatra Mts. Biologia, Bratislava 62 (2): 144-147.

Pišút I. 1997. Interessantere Flechtenfunde aus der Slowakei 4. Bull. Slov. Bot. Spoločn., Bratislava 19: 68-71.

Stenroos S. 1989a. Taxonomy of the Cladonia coccifera group. 1. Ann. Bot. Fennici 26: 157-168.

Stenroos S. 1989b. Taxonomy of the Cladonia coccifera group. 2. Ann. Bot. Fennici 26: 307-317.

Wirth V. 1995. Die Flechten Baden-Württembergs. 1. Verlag E. Ulmer, Stuttgart, 527 pp.

Zając A. 1978. Atlas of distribution of vascular plants in Poland (ATPOL). Taxon 27: 481-484. 


\section{Cladonia metacorallifera, nowy porost dla Karpat Wschodnich}

\section{Streszczenie}

Cladonia metacorallifera Asahina jest kieliszkowato zakończonym porostem należącym do sekcji Cocciferae (Delise) A. Evans. Duża zmienność morfologiczna taksonów z tej sekcji wciąż stwarza problemy taksonomiczne i utrudnia prawidłową identyfikację gatunków (por. Stenroos 1989a; Osyczka 2009). Cechą charakterystyczną C. metacorallifera są liczne łuseczki na ogół gęsto rozmieszczone na całej długości podecjów oraz czerniejące fragmenty plechy widoczne w miejscach pozbawionych kory i łuseczek. Cladonia metacorallifera wytwarza kwas usninowy, didymowy oraz skwamatowy (lub tamnoliowy). Ta właściwość chemiczna jest ważną cechą diagnostyczną gatunku. Istotne cechy taksonomiczne odróżniające $C$. metacorallifera od morfologicznie podobnych taksonów z sekcji Cocciferae (np. C. coccifera (L.) Willd., C. diversa Asperges lub C. borealis S. Stenroos) zawarte zostały w kilku publikacjach (np. Stenroos 1989b; zobacz również: Kowalewska, Kukwa 2004; Osyczka et al. 2006).

W Polsce po raz pierwszy $C$. metacorallifera znaleziono na jednym stanowisku w masywie Śnieżki w Karkonoszach (Kowalewska, Kukwa 2004), następnie podano go z dwóch stanowisk w polskiej części Tatr Wysokich (Osyczka et al. 2006). W wyniku rewizji materiałów zielnikowych porostów należących do $C$. coccifera s.l., zdeponowanych w zielniku lichenologicznym Uniwersytetu Pedagogicznego w Krakowie (KRAP-L), stwierdzono występowanie C. metacorallifera również w polskiej części Bieszczadów. Jest to pierwsze doniesienie o występowaniu tego gatunku w Karpatach Wschodnich.

Nowe stanowisko C. metacorallifera znajduje się w granicach Bieszczadzkiego Parku Narodowego, na zachodnim zboczu masywu Rozsypańca, na wysokości 1153 m n.p.m., ponad górną granicą lasu, w obrębie rumoszu skalnego. Stanowisko to charakteryzuje się wysokim nasłonecznieniem i ekspozycją południowo-zachodnią. Porost ten rósł wśród mchu na humusie $(\mathrm{pH}=4.65)$.

Występowanie C. metacorallifera w Polsce prawdopodobnie ograniczone jest do niewielkich populacji rozproszonych w obszarach wysokogórskich wzdłuż południowej granicy kraju. 